\title{
ACCOMMODATION IN A DIALECT CONTACT SITUATION
}

\author{
José Esteban Hernández
}

\begin{abstract}
RESUMEN
En este estudio se examinan los patrones de distribución que se manifiestan en una situación de contacto dialectal entre hablantes del español salvadoreño y mexicano en Houston, Texas. Dos variables, el voseo (uso del pronombre vos de segunda persona y la morfología correspondiente) y el andar transitivo (uso de andar para significar el llevar algo en sí mismo), se comparan a través de entrevistas sociolingüísticas llevadas a cabo por un hablante del español mexicano entre cuatro grupos de hablantes del español salvadoreño. La mayor distribución cuantitativa del voseo y del andar transitivo en el grupo que se entrevistó en El Salvador que en cualquiera de los grupos que se entrevistaron en Houston muestra que los informantes en Houston tienden a acoplarse al habla del entrevistador mexicano. Las diferencias cuantitativas entre los diferentes grupos en Houston nos indican que la edad del informante al momento de arribo al área de contacto dialectal influye en los patrones de distribución. Asimismo, las diferencias en la distribución del voseo y del andar transitivo sugieren que los informantes parecen estar más conscientes de algunas características dialectales que de otras.
\end{abstract}

\begin{abstract}
This study examines the distributional patterns evidenced in a dialect contact situation between speakers of Mexican and Salvadoran Spanish in Houston, Texas. Two variables, voseo (use of second person pronoun vos and its corresponding morphology) and transitive andar (use of andar to mean "carry something on one's person'), are compared in sociolinguistic interviews conducted by a speaker of Mexican Spanish among four groups of Salvadoran Spanish speakers. Higher frequencies of both voseo and transitive andar in the group interviewed in El Salvador than any of the groups interviewed in Houston show that the informants in Houston tend to accommodate to the Mexican interviewer. Differences between the Houston groups indicate that distributional patterns are influenced by the informant's age of arrival to the area of dialect contact. At the same time, distributional differences between voseo and transitive andar suggest that informants seem to be more aware of the use of some dialect features than others.*
\end{abstract}

\section{Introduction}

The description and analysis of linguistic patterns of Central American communities in the United States constitutes an important component of Spanish linguistic research that has been for the most part overlooked. Lipski (2000: 190) points out that "Because of the difficult conditions under which they [have] arrived and lived, the language and culture of Central Americans in the United States have not received an acknowledgment proportional to the 
numerical strength of this population". Trends in Central American immigration to the United States during the 1980's and 1990's show the numerical importance that the group has acquired. For example, figures from the 1990 census indicate that at least 1,323,830 persons claimed Central American origin in the United States. When we look at national origin, 565,081 Salvadorans constitute the largest Central American group in the United States. As a result of their growing numbers, Salvadorans have become a fast growing group within different Hispanic communities, which has in turn caused the diversification of the Hispanic population across the United States. Table 1 shows the major distribution of Salvadorans by state and the District of Columbia.

Table 1

Distribution of Salvadorans in the United States: the top five states and the District of Columbia

\begin{tabular}{|lr|}
\hline California & 338,769 \\
Texas & 58,128 \\
New York & 47,350 \\
Virginia & 23,537 \\
Florida & 12,400 \\
Washington D.C. & 10,513 \\
\hline
\end{tabular}

At the state level, we see that 58,128 Salvadorans made Texas the state with the second largest Salvadoran population, surpassed only by 338,769 Salvadorans in California. The population breakdown in major metropolitan areas across the United States is as follows.

Table 2

Distribution of the six major Salvadoran populations by metropolitan areas

\begin{tabular}{|lr|}
\hline Los Angeles-Anaheim-Riverside & 274,788 \\
New York-Northern New Jersey-Long Island & 63,676 \\
San Francisco-Oakland-San Jose & 52,438 \\
Washington D.C.-MD-VA & 51,893 \\
Houston-Galveston-Brazoria & 40,475 \\
Miami-Fort Lauderdale & 9,118 \\
\hline
\end{tabular}

The 1990 census indicates that a total of 625, 929 persons claimed Mexican heritage in the Houston area. We should state that while the Mexican origin community has been well established in the area since the middle of the 1800's, Salvadoran immigration to the area represents a recent phenomenon; its major increase occurred during the 1980's at the peak of civil conflict in El Salvador. Between 1980 and 1990, for example, 345,942 Salvadorans immigrated to the United States. Thus, national immigration trends show that out of the 565,081 persons that claimed Salvadoran origin in the 1990 census, 458,678 were foreign born 
and only 106,405 were born in the United States. The flow of Salvadoran immigration to the Houston area has continued, mainly because the end of the civil war did not bring an answer to the socioeconomic problems which gave rise to the conflict.

While the Mexican community undoubtedly constitutes the largest Spanish-speaking group in the area, it is difficult to estimate the size of the Salvadoran community in Houston. Consequently, projections of the Salvadoran population vary. First, a significant part of the Salvadoran population that has entered illegally for the most part goes unreported in census figures. Then, the steady growth in legal and illegal immigration within that ten year time span in which the census is conducted can only be predicted. For example, Lipski (1988: 95) believes that the 100,000 mark "has been surpassed even by the most conservative estimates". In a sociological study, Rodriguez (1987: 9) estimates that "undocumented Salvadorans in Houston probably number over 50,000”. At any rate, the official census figures alone make Salvadorans the second largest Spanish-speaking group in the Houston area ${ }^{1}$.

These demographics have facilitated the interaction between Mexicans and Salvadorans in the Houston area. People of Mexican origin in Houston occupy several well established neighborhoods, where they are the overwhelming majority or maintain an important presence. Salvadoran immigrants have mainly sought residence within these established enclaves, where stores, restaurants, and other specialized businesses cater mainly to the Spanish-speaking community. Rodriguez (1987: 5-6) corroborates the impact of undocumented Central American immigration on Mexican housing patterns in Houston, and states that "A large segment of undocumented Central Americans have settled in the old Mexican/Chicano barrios where Mexican immigrants are concentrated.” Lipski (1988: 98) also reports that Salvadoran immigrants of lower working class and middle class socioeconomic levels tend to live in primarily Hispanic neighborhoods. Findings by Rodriguez (1987: 20) confirm that undocumented Salvadorans usually work alongside undocumented workers of other nationalities. This tendency is also reaffirmed by Lipski (1988: 99) who notes that "a very high percentage [of Salvadorans] work with Mexicans, and nearly all Salvadoran immigrants patronize stores and restaurants where Mexicans and Mexican Americans are found in large numbers". Thus, economic, laboral, courtship, friendship, and kinship bonds between Salvadorans and Mexicans have grown in the last two decades.

In this article we analyze the effects that this dialect contact situation between Salvadorans and Mexicans has on the Salvadoran Spanish in Houston, Texas. The study measures the degree of accommodation that occurs when Salvadoran informants interact with a Mexican interviewer. Two linguistic variables, voseo and transitive andar, that may differ in their degree of speakers' awareness are explored. The rest of this paper is organized as follows. Section 2 is a pilot study that compares dialect awareness among Mexicans living in two different Southwestern cities. Section 3 is a summary of accommodation theory. Sections 4 describes the data collection process and the methodology used. Section 5 accounts for the distinct uses of each linguistic variant studied in two varieties. Section 6 presents and interprets the variational patterns found in the data. Finally, Section 7 offers some concluding remarks. 


\section{Dialect awareness in two communities: a pilot study}

Much work indicates that language contact does not occur under situations of neutral emotions and perceptions (Weinreich 1953, Thomason and Kaufman 1988). Rather, language groups in contact usually form impressions and opinions about each other that reflect and shape the type of social interaction; this is also true of dialect contact. For this reason, it comes as no surprise that speakers of a language also have perceptions about varieties of their native language as spoken by other groups. This ability to differentiate between dialects helps speakers to imitate a specific accent. For instance, in looking at speakers of British English, Trudgill (1986: 12) suggests that salient features of American English are usually produced in those cases in which speakers want to sound like Americans (e.g. telling jokes, acting a role). Saliency as explained by Trudgill (1986: 12) refers to those features that are "most prominent in the consciousness" of speakers. This goes back to the Labovian notion that sociolinguistic markers have a high level of awareness.

To compare awareness about specific dialect features in Salvadoran Spanish, eleven speakers of Mexican Spanish, living in Houston and Albuquerque, New Mexico were asked to determine the origin of five speakers in five different taped conversations that were extracted from interviews conducted among Salvadorans in Houston. All participants were speakers of Northern Mexican varieties that do not share those features in the conversations with Salvadoran Spanish. The pilot study was conducted in Houston, primarily because of the exceptional opportunity offered by the dialect contact situation. According to the 1990 census, persons of Mexican origin account for $82 \%$ of the total Hispanic population, and persons of Salvadoran origin comprise $5 \%$ of the total Hispanic population ${ }^{2}$. Albuquerque was chosen because Mexicans also constitute the largest immigrant Hispanic subgroup. Like Houston, Albuquerque has constantly received waves of Mexican immigration during this century. The 1990 census showed that 70,145 persons, $53.3 \%$ of the total Hispanic population, claimed Mexican origin in the Albuquerque metropolitan area ${ }^{3}$. However, the 1990 census also showed that only 253 Salvadorans, $0.001 \%$ of the total Hispanic population, lived in the Albuquerque metropolitan area. Consequently, we tried to evaluate whether Mexicans in Houston, where Salvadorans are a significant presence, differed from Mexicans in Albuquerque, where there is no significant Salvadoran presence, in their awareness of certain features present in this variety. More specifically, we also wanted to look at the participant's level of awareness between phonological and morphological features in Salvadoran Spanish. Six different participants in Houston had the opportunity to listen to two different taped conversations each, for a total of twelve responses. To compare these results, five participants in Albuquerque had the opportunity to listen to two different taped conversations each, for a total of ten responses. Although all speakers in the taped conversations were Salvadorans, "El Salvador" was not an option in the place of origin. Instead, participants were asked to choose among several Mexican states or de otro país 'from another country', where they could write in any country (See APPENDIX A).

Because we were trying to determine whether participants relied more on phonological, lexical or morphosyntactic features in their recognition of Salvadoran Spanish, the five taped conversations used differed in their phonological, lexical, and grammatical content. Figure 1 summarizes the features found in each conversation, which are not part of the Northern Mexican varieties of the participants. 
Conversation 1

$(\mathrm{JG} / 2 / 14)^{4}$

$\begin{array}{ll}\text { Phonological: } & / \mathrm{n} / \rightarrow[\mathrm{\eta}] /{ }_{-} \$ \\ \text { Morphosyntactic: } & \text { none } \\ \text { Lexical: } & \text { none }\end{array}$

Conversation 2:

(MM/1/32)

$\begin{array}{ll}\text { Phonological: } & / \mathrm{n} / \rightarrow[\mathrm{n}] /{ }_{-} \$, / \mathrm{s} / \rightarrow[\mathrm{h}] /{ }_{-} \$, / \mathrm{b} / \rightarrow[\mathrm{b}] / \mathrm{V}_{-} \mathrm{V} \\ \text { Morphosyntactic: } & \text { none } \\ \text { Lexical: } & \text { none }\end{array}$

Conversation 3:

(RH/1/55)

$\begin{array}{ll}\text { Phonological: } & / \mathrm{n} / \rightarrow[\mathrm{n}] / \_\$, / \mathrm{s} / \rightarrow[\mathrm{h}] /{ }_{-} \$, / \mathrm{s} / \rightarrow \square / \_\$ \\ \text { Morphosyntactic: } & \text { Use of adjective }+ \text { copula, la cerveza muy cara está. } \\ \text { Lexical: } & \text { Use of ¿va? 'right?' instead of ¿verdad? as in } \\ & \text { Mexican Spanish. }\end{array}$

Conversation 4:

(GL/2/20)

Phonological: $\quad / \mathrm{n} / \rightarrow[\mathrm{y}] / \_\$, / \mathrm{s} / \rightarrow[\mathrm{h}] / \_\$, / \mathrm{b} / \rightarrow[\mathrm{b}] / \mathrm{V} \_\mathrm{V}, \mathrm{r} \rightarrow \mathrm{c} /{ }_{\text {\# }}$ Lexical: Use of a saber 'who knows' instead of ¿quién sabe? As in Mexican Spanish.

Conversation 5:

$(\mathrm{AC} / 1 / 39)$

$\begin{array}{ll}\text { Phonological: } & / \mathrm{n} / \rightarrow[\mathrm{y}] /{ }_{-} \$, / \mathrm{s} / \rightarrow[\mathrm{h}] / \_\$, / \mathrm{s} / \rightarrow \mathrm{G} /{ }_{-} \$, / \mathrm{b} / \rightarrow[\mathrm{b}] / \mathrm{V}_{-} \mathrm{V} \\ \text { Morphosyntactic: } & \text { Use of voseo }(\text { See examples } 2-10) . \\ \text { Lexical: } & \text { none }\end{array}$

\section{Figure 1}

Some phonological, morphosyntactic and lexical features in five taped conversations with Salvadorans

In Figure 1 we see that conversation 1 shows only /n/ velarization. Conversation 2 presents the use of /n/ velarization, /s/ aspiration, and an intervocalic /b/ occlusiveness. Conversation 3 shows $/ \mathrm{n} /$ velarization, /s/ aspiration and deletion, in addition to the use of adjective + copula, as in la cerveza muy cara está 'the beer is very expensive', and the use of ¿va? 'right?', as in quizás se la creyeron, ¿va? 'maybe they believed it, right?'. In Salvadoran Spanish verdad, suffers greater reduction than in Northern Mexican Spanish and is usually pronounced $v a$ or veá. Conversation 4 shows all the phonological features present in Conversation 2, /r/ deletion, and the use of a saber 'who knows', as in yo creo que era cuestión de querernos dejar ahí o a saber qué 'I think it was a matter of wanting to leave us there, who knows what'. Finally, Conversation 5 shows most of the characteristic phonological features present in Salvadoran Spanish, and the use of voseo, as in entre más rápido echás el viaje 'the faster you make the trip'.

The taped conversations with prevailing phonological features were always played first, while those combining phonological with lexical or grammatical features were always 
played second. Consequently, the numerical order in Figure 1 was never altered to prevent participants from listening to conversations that had lexical or grammatical features before listening to those with primarily phonological features.

Table 3

Origin recognition of Salvadoran speakers in five different conversations among Mexican evaluators in Houston and Albuquerque

\begin{tabular}{|c|c|c|c|c|}
\hline CONVERSATION & ORIGIN & $\begin{array}{c}\text { HOUSTON } \\
\text { RESPONSES }\end{array}$ & ORIGIN & $\begin{array}{c}\text { ALBUQUERQUE } \\
\text { RESPONSES }\end{array}$ \\
\hline 1 & $\begin{array}{l}\text { Tamaulipas, México } \\
\text { Veracruz, México } \\
\text { Guerrero, México } \\
\text { El Salvador }\end{array}$ & $\begin{array}{c}1 \\
1 \\
1 \\
\text { none }\end{array}$ & $\begin{array}{c}\text { Tamaulipas, México } \\
\text { mexicoamericano } \\
\text { El Salvador }\end{array}$ & $\begin{array}{c}1 \\
1 \\
\text { none }\end{array}$ \\
\hline 2 & $\begin{array}{l}\text { Veracruz, México } \\
\text { El Salvador }\end{array}$ & $\begin{array}{l}1 \\
2\end{array}$ & $\begin{array}{l}\text { mexicoamericano } \\
\text { El Salvador }\end{array}$ & $\begin{array}{c}2 \\
\text { none }\end{array}$ \\
\hline 3 & El Salvador & 3 & $\begin{array}{c}\text { Veracruz, México } \\
\text { Guerrero, México } \\
\text { El Salvador }\end{array}$ & $\begin{array}{c}1 \\
1 \\
\text { none }\end{array}$ \\
\hline 4 & El Salvador & 2 & $\begin{array}{c}\text { Jalisco, México } \\
\text { El Salvador }\end{array}$ & $\begin{array}{l}2 \\
1\end{array}$ \\
\hline 5 & El Salvador & 1 & $\begin{array}{c}\text { Jalisco, México } \\
\text { El Salvador }\end{array}$ & $\begin{array}{c}1 \\
\text { none }\end{array}$ \\
\hline
\end{tabular}

Table 3 shows that the Houston participants recognized the Salvadoran origin of the speakers in the conversations with greater accuracy than the participants in Albuquerque. For example, if we look at responses given for Conversation 2, two out of three participants in Houston suggested Veracruz, Mexico as the place of origin, while one suggested El Salvador. On the other hand, the two Albuquerque participants suggested a Mexican American origin. All Houston participants recognized the origin of speakers in Conversations 3, 4, and 5, but only one in Albuquerque recognized the speaker in Conversation 4 as Salvadoran ${ }^{5}$. Participants in Houston recognized speakers in the conversations as Salvadorans 7 out of 12 times for a 58\% accuracy. On the other hand, participants in Albuquerque recognized speakers in the conversation as Salvadorans only 1 out of 10 times for a $10 \%$ accuracy. We can infer that this reflects a lack of awareness of the characteristic features that distinguishes the Salvadoran variety from the Mexican variety.

A more important finding is the fact that the awareness of participants in Houston increases as we descend along Table 3. Once they could rely on lexical or grammatical features, participants in Houston were able to determine place of origin with a $100 \%$ accuracy. That is, awareness of the specific dialect features heightened as the participants in Houston shifted, from relying completely on phonological features, to relying additionally on lexical 
and grammatical features. On the other hand, participants in Albuquerque were not aware of the characteristic features of this dialect. Table 3 clearly shows that phonological features alone are not as perceptible in the Houston dialect contact situation, as the combination of phonological, lexical, and grammatical features seems to be. If we consider that Conversations 1 and 2 show only phonological traits, we see that participants in Houston recognized speakers in the conversations as Salvadoran 1 out of 6 times for a $16.6 \%$ accuracy. This is compared to a $0 \%$ accuracy among participants in Albuquerque. Again, the accuracy of the participants sharply differs in the responses of those conversations that combined phonological and grammatical features. Here, participants in Houston recognized speakers as Salvadorans 6 out of 6 times for a 100\% accuracy. Participants in Albuquerque only recognized speakers as Salvadoran 1 out of 6 times for a 17\% accuracy.

The areas of Veracruz and Guerrero, two of the three Mexican states indicated as place of origin for speakers in conversations 1 and 2 in Houston, share similar phonological traits with Salvadoran Spanish. Lipski (1994: 282) lists velarization of word final /n/ and weakening of syllable final /s/ as characteristic features of these two Mexican varieties. These two characteristics are also present in Salvadoran Spanish. In contrast, the Tamaulipas and the Mexican American variety, indicated as the origin of Speakers 1 and 2 in Albuquerque, do not share those features with Salvadoran Spanish. Table 3 confirms that Mexican evaluators in Houston have a greater awareness of some morphosyntactic and lexical features of the dialect features found in the conversations. Two previous observation made by Lipski (1989: 105) are also supported: 1) that in Mexico, speakers of Mexican varieties are generally not aware of the use of voseo by Central Americans (we can infer that this can be generalized to other dialect features and to Mexicans who move to areas in the United States without a significant Central American presence); 2) that dialect contact in the United States brings an "increased awareness of linguistic differences" in speakers of Mexican varieties.

\section{Accommodation theory}

Trudgill (1983:143) describes accommodation "as adjustments in pronunciation and other aspects of linguistic behavior in terms of a drive to approximate one's language to that of one's interlocutor, if they are regarded as socially desirable and/or if the speaker wishes to identify them with them and/or demonstrate good will towards them." Thus, accommodation of Salvadoran speakers may imply an attempt by speakers to identify with, or to present themselves as more pleasant to the Mexican interviewer. Accommodation could also mean that certain features of the Salvadoran variety have acquired a social meaning that reflects the social status of its users, even though this is beyond the scope of the present study. In this sense, the data to be presented in the following section poses some of the questions found in previous dialect contact research. Mainly, what makes a speaker of variety $A$ adopt a feature of variety $B$ or vice versa? What features are more easily adopted into a specific variety and favored over original ones? Are speakers more aware of the use of certain dialect features than others?

It has been argued that speech accommodation varies according to similarities and differences in the varieties in contact. In some cases, dialect contact involves historically related, although not necessarily similar, varieties. In this case, speakers of variety $A$ more 
than likely have an idea of what variety $B$ sounds like, and vice versa. Here, speakers also recognize those specific characteristics that distinguish each variety in contact. Thus, if speakers in the former case resort to an accommodation strategy, they do so by altering the frequency of the preferred variants, which already form part of their speech repertoire. This argument goes back to Trudgill's idea that "accommodation within the speech community [...] involves altering the frequency of usage of particular variants or variables over which the speaker already has control. Accommodation beyond the speech community, on the other hand, may well involve the adoption of totally new features of pronunciation (1986: 12)." Accommodation in a dialect contact situation brought about by immigration, as in the case of Salvadoran and Mexican Spanish, may involve (1) increasing the frequency of preferred variants which already form part of the speaker's speech repertoire, (2) decreasing proportionally those that are stigmatized, and/or (3) integrating those features which are absent from the speaker's speech repertoire. In the case of dialect contact in Houston, dialects from two different Spanish speaking areas have met in a predominantly English-speaking environment. However, people of Mexican origin in the state constitute an important numerical presence with a strong historical vinculum.

In the present situation, even though there is an intense contact between the two communities, the attitudes of Mexicans toward Salvadorans tend to be negative when they pertain to language. For example, Mexicans in Houston have adopted the use of ethnic slurs such as guanaco $^{6}$ to refer to Salvadorans. Mexicans also tend to imitate what they perceive to be characteristic, perhaps stigmatized, features of Salvadoran Spanish. For instance, Mexicans may imitate the use of [h] instead of [s] syllable finally, and the use of vos 'you' instead of tú 'you'. Otherwise, interaction occurs without major points of friction. Lipski (2000:196) notes that "On a personal level, Salvadorans of all socioeconomic groupings feel no negative emotions toward Mexicans or Mexican Americans but rather regard them as fellow Latinos." The two groups perform and work in similar jobs, attend the same social events, and live in the same neighborhoods. Mexican Spanish in Houston has acquired the use of Salvadoran lexical items for foods, such as curtido 'type of salad' and pupusa 'round maize pancake', but other grammatical levels of Mexican Spanish do not seem to be affected.

\section{Data and methodology}

Fifteen hours and thirty minutes of speech samples were recorded by the same interviewer from thirteen informants in Houston, and two informants in El Salvador. The type of conversation varied from a semi-directed style, where the interviewer asked about topics that affected Salvadorans in Houston and in El Salvador, to a more casual style, where informants introduced their own topics of interest. Most informants talked about the differences of life in El Salvador and Houston, adversities experienced during the civil war, the journey from El Salvador to Houston, challenges in adapting to life in the United States, and relations between Mexicans and Salvadorans in the community. We should state that even though the analysis of possible sociolinguistic correlations could prove to be extremely productive, the number of occurrences of the two variables only permitted the more general analysis of the distributional patterns in the dialect contact situation explained below. 
The speech sample of the two informants living in El Salvador, and that of one Houston informant who had arrived two weeks prior to the interview served to document variation of dialect features in the Salvadoran variety "in situ". I will refer to these speakers as the $E l$ Salvador group. All other Houston informants had lived in the area for at least five years. These twelve informants were distributed into three groups, according to age of arrival in Houston. Group 1 consists of four speakers that arrived in the area at 21 years of age or older, Group 2 consists of four speakers that arrived between 14 and 20 years of age, and Group 3 consists of four speakers that arrived between ages 3 and 11. The division in the age of arrival between Groups 2 and 3 was done considering Chamber's (1992: 689) observation that “A person seven or under will almost certainly acquire a new dialect perfectly, and a person 14 or over almost certainly will not. In between those ages, people will vary." The informants who arrived in the area at the ages of 10 and 11 fell below the 14 year old mark; therefore, I included those informants in Group 3. This cut-off point agrees with Silva-Corvalán's research who notes that "the structures of one's native language are usually firmly acquired" around 11-12 (1994: 15). In order to see the variational patterns within those speakers of the Salvadoran variety who, according to Chambers (1992), "almost certainly will not" acquire new dialect features, the speakers who arrived in Houston at age 14 or older were divided into Groups 1 and 2. The partition between Groups 1 and 2 was based on the assumption that those who arrived between 14 and 20 had more opportunities for exposure to the Mexican variety outside the home environment at an earlier age. For instance, two informants in Group 2 attended part of their high school years in Houston. Another informant in Group 2 shared a room with a group of Mexican friends upon arriving in Houston. Figure 2 summarizes the characteristics of the four groups.

\begin{tabular}{|lccc|}
\hline & SPEAKER & AGE OF ARRIVAL & YEARS IN HOUSTON \\
\hline El Salvador: & AA & - & - \\
& CR & - & - \\
Group 1: & EF & - & - \\
(21-older) & & & $\mathbf{8}$ \\
& RH & $\mathbf{5 5}$ & 17 \\
& AC & $\mathbf{3 9}$ & 5 \\
MMa & $\mathbf{3 4}$ & 21 \\
Group 2: & MM & $\mathbf{3 2}$ & 8 \\
(14-20) & & & 8 \\
& RM & $\mathbf{2 0}$ & 30 \\
& GL & $\mathbf{2 0}$ & 8 \\
Group 3: & NB & $\mathbf{1 8}$ & 12 \\
(11-younger) & JG & $\mathbf{1 4}$ & 16 \\
& RO & $\mathbf{1 1}$ & 15 \\
& ED & $\mathbf{1 0}$ & 18 \\
\hline
\end{tabular}

Figure 2

Coding of Salvadoran speakers into four groups by age of arrival and years of residence in Houston 
The interviewer, a speaker of a Northern Mexican variety, lived for over four years in the predominantly Spanish speaking southeast part of Houston, where most of the data was collected. We hoped this would help in collecting more reliable samples of variation patterns in the speech of the Houston Salvadoran informants. At the same time, we expected that if accommodation occurred, it would take place obeying patterns already present in the community. Without exception, a reciprocal use of casual pronominal forms (i.e. tú or vos 'you casual') was used between the interviewer and speakers in Group 2, Group 3, the informants in El Salvador Group, and the two males in Group 1. On the other hand, the interviewer used usted 'you formal' to communicate with the two female members of Group 1, but received the use of a casual pronominal form from them.

\section{The linguistic variables}

The degree of accommodation was quantified by looking at contrasting distributional patterns present in Salvadoran and Mexican Spanish. Thus, voseo, the preferred casual pronominal form in Salvadoran Spanish, contrasts with tuteo, the preferred form in Mexican Spanish; and the transitive use of andar, to express carrying something on oneself, contrasts quantitatively with verbs like traer, llevar, cargar, and portar in Mexican Spanish. The choice of voseo, perhaps the most characteristic morphosyntactic feature of Central American Spanish, seemed obvious because previous studies have indicated that Salvadorans favor the use of tuteo when they come in contact with speakers of other varieties of Spanish (Lipski 1988, 1994). On the other hand, the use of andar in transitive constructions has not been documented as much, and studies have not claimed that Salvadorans will replace andar with another lexical item when in contact with speakers of other Spanish varieties.

\subsection{Voseo and tuteo}

Usage of tuteo extends across most of Mexico, except parts of Chiapas and Tabasco, bordering Guatemala. Mexicans in Houston also prefer the use of tuteo. Voseo entails a change in the syllabic stress of conjugated verb forms, as in tú hablas $>$ vos hablás ${ }^{7}$ 'you speak'. This causes the appearance of monothongized forms of stem changing verbs as in tú puedes $>$ vos podés 'you can', the retention of the thematic vowel in monosyllabic forms as in ven > vení 'come here', and the use of regularized forms in some irregular verbs as in $\boldsymbol{d i}>$ decí 'say'. The quantified data only considers contrasting voseo and tuteo forms: the present indicative, the present subjunctive, and the imperative. Thus, future and imperfective forms (hablarás 'you will talk', hablabas 'you used to talk') are not considered because they are identical in tuteo and voseo, as well as shared present indicative forms like vas, das and ves. Preterit was not considered in our study due to the common tendency of speakers in tuteo varieties to use analogical forms, such as (tú) hablastes 'you spoke, talked', along with prescriptive forms, such as (tú) hablaste 'you spoke, talked'. The use of tuteo is illustrated in (1). 
1. - Tienes que conocer a la persona primero. (RH/1/55)

- 'You have to know the person first.'

The next examples illustrate the use of voseo.

2. - Y la mujer me decía: venite, traete a la niña. (RH/1/55)

- 'And my wife would say to me: come here, bring the girl.'

3. - Ese dinero antes no entraba porque no había mucha gente de allá aquí, hoy hay mucha. En Los Ángeles, olvidate, está lleno. (AC/1/39)

- 'That money did not enter because there were not many people from there here. In Los Angeles, forget it, it is full.'

4. - Me paraban y me decían: llevanos a tal parte que, que vamos a hacer un operativo. (RH/1/55)

- 'They used to stop me and they used to say: take us to such place that, that we are going to do an operation.'

5. - Así que recogían todo lo que ellos querían. Ya, decían: parale, le decían, en una parte deshabitada. (RH/1/55)

- 'So they picked up everything they wanted. Ready, they would say: stop, they would tell him, in an uninhabited place.'

\subsection{Andar and traer}

The verb andar, as in anda buscando algo 'he is looking for something', functions as an auxiliary in progressive and copular constructions, as well as a lexical verb meaning 'walk, go, and go around', in Mexican and Salvadoran Spanish. In the latter, andar has also acquired an innovative use that expresses the idea of carrying something on one's person (Lipski 1994: 260). In this context, andar is primarily used as a transitive verb. On the contrary, Mexican Spanish employs a variety of verbs to express the same idea, such as traer 'to bring', llevar 'to take, wear', portar 'to carry (a weapon)', and cargar 'to carry'. In Salvadoran Spanish most of these verbs are usually restricted to their original lexical meaning. For example, in Salvadoran Spanish traer usually means to bring, but in Mexican Spanish it additionally implies carrying or bearing something on one's person, as illustrated in (6) where the speaker reports on his response to the demand for money made by his Salvadoran companion during their trip across Mexico.

6. - No, yo no traigo feria tampoco, le digo. Me dice que: sí traes. ¿Sabes qué ghey?, no traigo, le dije. No traigo y no estés fregando.

- 'No, I do not have money on me either, I tell him. He tells me that: you do have [money] on you. You know what man?, I do not have [money] on me, I said. I do not have [money] on me and stop bugging me.' (RM/2/20)

The use of andar as a transitive verb is illustrated in (7) to (9). 
7. - Allí llegan todos. Tenías que andar vehículo pa' llevartelos. (AC/1/39)

- 'Everybody arrives there. You had to take a vehicle to take them.'

8. - no, sí, puedes andar arma... (AC/1/39)

- 'no, yes, you can carry a weapon...'

9. - Ya va a hacer ahora en mayo tres años que me entregaron una virgen y la ando de peregrina $y . .$.

- ¿La qué?

- Una virgen, una virgen de... Es la virgen de Fátima, y la, y yo la, esta virgen... Ya ahora ya ando también una virgen de Guadalupe. Las ando de peregrinas, de casa en casa. $(N B / 2 / 18)$

- 'Now in May it is going to be three years that they gave me a virgin and I carry her on pilgrimages and...'

- 'You what?'

- 'A virgin, a virgin of... It is the virgin of Fatima, and, and I, this virgin... And now I also carry a virgin of Guadalupe. I carry them on pilgrimages, from house to house.'

\section{Analysis of the variational patterns}

Table 4

Distribution of tuteo-voseo and traer (\& other)-andar in three groups of Salvadoran speakers by age of arrival

\begin{tabular}{|c|c|c|c|c|c|c|}
\hline & \multicolumn{2}{|c|}{ EL SALVADOR } & \multicolumn{2}{|c|}{ GROUPS $1 \& 2$} & \multicolumn{2}{|c|}{ GROUP 3} \\
\hline & \multirow[b]{2}{*}{$\mathrm{N}$} & \multirow[b]{2}{*}{$\%$} & \multicolumn{2}{|c|}{$\begin{array}{l}\text { AGE OF ARRIVAL } \\
\text { HOUSTON } 14+\end{array}$} & \multicolumn{2}{|c|}{$\begin{array}{l}\text { AGE OF ARRIVAL } \\
\text { HOUSTON 3-11 }\end{array}$} \\
\hline & & & $\mathrm{N}$ & $\%$ & $\mathrm{~N}$ & $\%$ \\
\hline \multicolumn{7}{|l|}{$\begin{array}{l}\text { MORPHOLOGICAL } \\
\text { VARIATION: }\end{array}$} \\
\hline TUTEO & 19 & $11.8 \%$ & 240 & $94.5 \%$ & 38 & $100 \%$ \\
\hline VOSEO & 142 & $88.2 \%$ & 14 & $5.5 \%$ & - & $0 \%$ \\
\hline TOTAL & 161 & $100 \%$ & 254 & $100 \%$ & 38 & $100 \%$ \\
\hline \multicolumn{7}{|l|}{ LEXICAL VARIATION: } \\
\hline TRAER \& OTHER & 2 & $18.2 \%$ & 21 & $70 \%$ & 11 & $68.8 \%$ \\
\hline$A N D A R$ & 9 & $81.8 \%$ & 9 & $30 \%$ & 5 & $31.2 \%$ \\
\hline TOTAL & 11 & $100 \%$ & 30 & $100 \%$ & 16 & $100 \%$ \\
\hline
\end{tabular}


Table 4 shows contrasting patterns of variation between speakers in El Salvador and Houston. In the El Salvador group, those dialect features previously labeled as characteristic of the Salvadoran variety were quantitatively favored: voseo $88.2 \%$ and transitive andar $81.8 \%$. We find the opposite distribution in the Houston groups where tuteo and traer \& other verbs are preferred. Percentages for the combination of Groups 1 and 2 (Houston 14 or older) do not differ sharply from Group 3 (Houston 11 or younger), other than the categorical use of tuteo in the latter group.

The high use of voseo among speakers recorded in El Salvador is surprising for two reasons. First, even though voseo is the preferred pronominal form of address in El Salvador, it has sustained ample opposition from more traditionalist views, which consider its use as a vulgar and uneducated form (Lipski 1988:103). There is also a strong association of tuteo with the upper socioeconomic levels of Salvadoran society. The inclination to use tuteo in commercial and political advertising, and in official governmental contexts is a direct consequence of this linguistic dichotomy, which subjects Salvadorans to a constant passive exposure to tuteo. Second, although the traditionalist view has far from caused the eradication of voseo ${ }^{8}$, linguistic attitudes have been said to materialize into linguistic insecurity when Salvadorans come in contact with speakers of other Spanish varieties (Lipski 1988:103). However, Table 2 indicates that speakers in El Salvador group maintained high levels of voseo in Salvadoran-Mexican interaction ${ }^{9}$. Looking at pronominal expression, we find that most verbal forms in the data were not accompanied by an expressed subject pronoun. However, an actual count of pronoun expression in El Salvador, shows that the interviewer was addressed 58 times as vos, as in vos sabés que sólo te dicen 'you know that they only tell you', and only two times as tú (by Speaker 3), as in creo que vos- tú ya lo conoces 'I think that you [vos]- you [tú] already know him'. This can be compared to 45 occurrences of tú and zero uses of vos among Groups $1 \& 2$ (Houston 14 or older). Therefore, even though we find variation of grammatical forms, the actual distribution of pronouns suggests that speakers in El Salvador rely on vos as the basic pronominal form in the conversation while Houston speakers rely on tú.

We see in Table 4, that tuteo first appears in the El Salvador group and culminates in the complete replacement of voseo in Group 3. The increase in the use of tuteo morphology from $11.8 \%$ in the El Salvador group to $94.5 \%$ in the combined total of Groups 1 and 2 can be interpreted as a possible reinforcement of the linguistic attitudes that speakers bring from El Salvador. Since voseo is the preferred grammatical form in El Salvador, increased appearance of tuteo in the speech of informants in Groups 1 and 2 may be interpreted as degrees of accommodation to the interviewer. The categorical distribution of pronominal forms in Group 3 could be interpreted as the maximum degrees of accommodation. This does not necessarily tell us much about the behavior of voseo in other environments. We suppose that all informants who arrived in Houston after the age of 14 or older came from a voseo predominant environment. However, there is no way to predict the actual level of feature exposure or acquisition of informants in Group 3. Perhaps, speakers of the age range present in Group 3 arrived in Houston at an age when they were exposed to higher levels of peer pressure or exposure to Mexican dialect features and attitudes.

A major difference between distribution of second person morphological forms and the distribution of verb choice in transitive "carry" constructions is that voseo reached categorical or almost categorical non-use in the Houston data, whereas quantitatively 
transitive andar maintained a more elevated presence: $30 \%$ in the combined Groups 1 and 2, and $31.2 \%$ in Group 3. Two verbs other than andar occurred in the El Salvador group: Speaker 2 used the verb portar 'carry a weapon', as in el arma que vos portás 'the weapon that you carry'; and Speaker 1 produced the only instance of traer. In groups 1, 2, and 3, substitutes for andar were traer, portar, and cargar. Speaker 12 produced all the instances of transitive andar in Group 3. This significant fact indicates that the sociolinguistic history of any given speaker can outweigh factors such as age of arrival in this contact situation: Speaker 12 arrived in Houston at age 3, and she is the only informant who has lived and grown in Southwest Houston, an area where Salvadorans are more numerous than in other parts of the city. Perhaps residence within particular Houston areas may be a significant factor in the present contact situation, even though this is certainly beyond the scope of the present study.

Again, the frequent mentions of Central American voseo contrasts with the few references of the transitive use of andar. In all likelihood, the documentation of attitudes towards voseo may parallel the degree of awareness that many Salvadoran speakers hold of the two morphological forms (i.e. voseo-tuteo). On the other hand, the absence of documentation of transitive andar in Central American Spanish may mirror the lack of awareness that speakers in El Salvador exhibit when they use andar as a transitive verb. That is, many speakers in El Salvador perceive tuteo as a more educated or "uppity" morphological choice, but the same distinction does not exist between transitive andar and traer \& other verbs. The results show that the quantitative distribution of tuteo/voseo forms, perhaps tied to a greater awareness of voseo, is affected to a greater degree than the distribution of andar/traer as a verb choice to express the idea of carrying something on one's person.

In section 3 we suggested that the contact situation increased Mexicans' awareness to some features of the Salvadoran variety. This is verified by comments made during the sociolinguistic interviews which indicate that perceptions sometimes develop into concrete judgments toward the Salvadoran variety, as in the next examples. In (10), antes 'before' refers to the speaker's adolescent years.

10. Antes [los mexicanos] me hacían chistes y quizás por eso no decía mucho (...) por decir cipote, o vos $o-(E D / 3 / 10)$

'Before they [Mexicans] used to make jokes and that is probably why I did not say much (...) for saying cipote 'boy', or vos, or-'.

11. y no sé nomás no quería [hablar] porque tal vez me iba- se iban a burlar de mí so entonces, este, aunque- yo no hablaba ¿verdá? como de El Salvador porque pues cuando viene aquí uno aprende lo de la demás gente $(C D / 3 / 8)$

'and I do not know I just did not want [to talk] because maybe I would- they would mock me so then, ugh, even though- I did not talk, right? like from El Salvador because when we come here we learn the ways of other people'.

Mexican attitudes toward the Salvadoran variety seem to have reinforced the negative linguistic perceptions of some of the informants. Differences in the rate of accommodation also suggest different degrees of feature awareness among the Salvadoran informants. This tendency to accommodate to the speech of the Mexican interviewer in our study variety has 
also been proposed by Schreffler (1994: 107) who states that "The desire of many Salvadorans to blend into the Mexican population encourages them to attempt to acquire ways of speaking that are generally associated with Mexicans. In order to achieve this goal, they must shed the linguistic trait that most readily identifies them as Salvadorans."

\subsection{Variation in speakers arriving in Houston at age 14 and older}

In this section, we analyze the distributional patterns of all informants who arrived in the Houston area at the age of 14 or older. Because speakers in these groups (1 and 2) originate in an environment where voseo and transitive andar are the predominant or categorical features, changes in the relative frequency of these features in the Houston Salvadoran variety may indicate the extent of accommodation between the speakers and the interviewer.

Table 5

Distribution of grammatical and lexical variation in two groups of Salvadoran speakers arriving in Houston at age $14+$

\begin{tabular}{|c|c|c|c|c|c|c|}
\hline & \multicolumn{2}{|c|}{$\begin{array}{l}\text { GROUP } 1 \\
\text { AGE OF ARRIVAL } \\
\text { HOUSTON } 21+\end{array}$} & \multicolumn{2}{|c|}{$\begin{array}{l}\text { GROUP } 2 \\
\text { AGE OF ARRIVAL } \\
\text { HOUSTON } 14-20\end{array}$} & \multicolumn{2}{|c|}{$\begin{array}{l}\text { GROUPS } 1 \& 2 \\
\text { AGE OF ARRIVAL } \\
\text { TOTAL } 14+\end{array}$} \\
\hline & $\mathrm{N}$ & $\%$ & $\mathrm{~N}$ & $\%$ & $\mathrm{~N}$ & $\%$ \\
\hline \multicolumn{7}{|l|}{$\begin{array}{l}\text { GRAMMATICAL: } \\
\text { PRONOMINAL USAGE: }\end{array}$} \\
\hline TUTEO & 98 & $89 \%$ & 142 & $98.6 \%$ & 240 & $94.5 \%$ \\
\hline VOSEO & 12 & $11 \%$ & 2 & $1.4 \%$ & 14 & $5.5 \%$ \\
\hline TOTAL & 110 & $100 \%$ & 144 & $100 \%$ & 254 & $100 \%$ \\
\hline \multicolumn{7}{|c|}{ LEXICAL: } \\
\hline TRAER \& OTHER & 5 & $45 \%$ & 16 & $84 \%$ & 21 & $70 \%$ \\
\hline$A N D A R$ & 6 & $55 \%$ & 3 & $16 \%$ & 9 & $30 \%$ \\
\hline TOTAL & 11 & $100 \%$ & 19 & $100 \%$ & 30 & $100 \%$ \\
\hline
\end{tabular}

Compared to the distribution of tuteo/voseo among speakers in the El Salvador group ( $11.8 \% \%$ tuteo and $88.2 \%$ voseo), Table 5 shows that voseo decreased considerably when Salvadorans, who arrived in Houston at age 14 and older, interacted with the Mexican interviewer: $11 \%$ in Group 1 and 1.4\% in Group 2. The lower use of voseo occurs in Group 2, which shows an almost complete preference for tuteo. Again, the present study cannot predict if the overwhelming preference of tuteo implies the existence of similar distributional patterns of voseo among Group 2 speakers in other contexts. That is, the present results show an 
accommodation process that occurs when Salvadorans informants interact with a speaker of Mexican Spanish. Further data that shows patterns of use among the Salvadoran community itself and in different contextual situations is needed to fill the limitations of the present study. However, the degrees of distribution show that age of arrival to the area is a significant factor in the accommodation process. Group 1 shows higher levels of use of voseo and transitive andar.

The different distributional patterns for tuteo/voseo and traer/andar also suggests that speakers of the two groups (1 and 2) maintain distinct linguistic behavior toward each characteristic feature. Here, the opposing attitudes towards voseo and andar, mentioned before, may influence the divergent variational patterns. For example, in Table 5, tuteo displays high levels of use during speaker/interviewer interaction (89\% in Group 1 and 98.6\% in Group 2). In contrast, the distribution of andar is slightly higher among speakers in Group 1: $45 \%$ for traer and $55 \%$ for andar.

\section{Conclusion}

We have shown that in the interaction between Mexican and Salvadoran interlocutors in this contact situation voseo and transitive andar, two features that distinguish Salvadoran Spanish from Mexican Spanish, diminish in their frequency of use. Thus, while speakers in El Salvador showed a strong quantitative preference for the use of these two features, voseo and transitive andar, among Salvadorans in Houston the use of tuteo became almost categorical. Traer \& other verbs also displayed an important increase in their frequency. However, the quantitative analysis shows that in Mexican and Salvadoran communication, voseo experienced a greater rate of accommodation than transitive andar. Based on differences in the distributional patterns of accommodation of the two features, we indicated that the greater rates of accommodation in voseo environments could be partially triggered by attitudes already present in El Salvador itself, which contrasted with the lack of awareness associated with the use of transitive andar. In this dialect contact situation, age of arrival also proved to be an important factor favoring accommodation. The present investigation would like to point to the need of further work that could shed light on variational patterns of language use among Salvadorans in differing contexts. This line of work may help in understanding the possible lasting effects of accommodation on Salvadoran Spanish in contact with other varieties of Spanish in the United States.

\section{Notes}

* I am grateful to Rena Torres Cacoullos (University of New Mexico) and Garland Bills (University of New Mexico) for providing valuable comments on this topic. I am also grateful to Esther Brown and Jessie A. Aaron for reading earlier versions of this study. Needless to say, all errors remain solely mine. I thank the Office of Graduate Studies

1. The Census 2000 figures showing specific ethnic and national origin breakdown of the Hispanic population in Houston are not available yet, although we can expect an increase in the official numbers of Salvadorans in Houston. 
2. The 5\% count was based on 1990 census figures for "Race and Hispanic Origin", which includes those born of Salvadoran parents. The 1990 census shows a much smaller count under "Place of Birth of Foreign-Born Persons". At any rate, the two counts should be seen as a conservative reflection of the actual Salvadoran population in Houston.

3. This does not include 60,030 people who claimed to be "other Hispanic". More than likely, this reflects the tendency of a significant part of the Hispanic population of the state to consider themselves "hispanos" or "nuevomexicanos".

4. In each example, the parentheses refer to the following information: (speaker/ group /age of arrival).

5. The evaluator in Albuquerque that identified speaker 4 moved to the area two and a half years ago from Los Angeles, California, a city with a strong Salvadoran presence. When asked how she was able to determine the origin of the person, she confirmed that she had Central American friends in Los Angeles, including Salvadorans.

6. This derogatory term is commonly used among Central Americans to refer disparagingly to Salvadorans (cf. Varela 1998-99:6-7).

7. Emphasis falls on the highlighted syllable.

8. From personal observation of pronominal use in San Sebastián, I can say that the use of the pronoun vos was categorical during Salvadoran-Salvadoran interaction. That is, tú never substituted vos in casual interactions.

9. Two informants in El Salvador had attained a university education, and one was currently enrolled in a university. This could in turn mean more exposure to prescriptive views. Level of formal Spanish language instruction in Houston was at most complete or incomplete elementary in all but one case in Group 1 and 2.

\section{Bibliography}

Chambers, J. K. 1992. “Dialect acquisition”. Language 68 (4): 673-705.

Lipski, John. 1988. "Central American Spanish in the United States: some remarks on the Salvadoran community". Aztlan. 17 (2): 91-123.

1989. "Salvadorans in the United States: patterns of intra-Hispanic migration". National Journal of Sociology. 3: 97-119.

1994. Latin American Spanish. New York: Longman.

2000. "The linguistic situation of Central Americans". En: McKay y Wong (Eds.), 189-215.

McKay, Sandra Lee y Sau-Ling Cynthia Wong (Eds.). 2000. New immigrants in the United States. Cambridge: Cambridge University Press. 
Rodríguez, Nestor P. 1987."Undocumented Central Americans in Houston: diverse populations". International Migration Review. 31 (1): 4-26.

Schreffler, Sandra B. 1994. "Second-person singular pronoun options in the speech of Salvadorans in Houston, Texas”. Southwest Journal of Linguistics. 13 (1/2): 101-119.

Silva-Corvalán, Carmen. 1994. Language contact and change: Spanish in Los Angeles. Oxford: Clarendon Press.

Thomason, Sarah Grey y Terrence Kaufman. 1988. Language contact, creolization, and genetic linguistics. Los Angeles: University of California Press.

Trudgill, Peter. 1983. On dialect. New York: Basil Blackwell.

1986. Dialects in Contact. New York: Basil Blackwell.

U.S. Bureau of the Census. (1993). 1990 Census of population-Social and economic characteristics: metropolitan areas. Washington, DC: U.S. Government Printing Office.

Varela, Beatriz. 1998-1999. "Discurso de incorporación: el español centroamericano de Luisiana”. Boletín de La Academia Norteamericana de la Lengua Española. 9-10: 1-40.

Weinreich, Uriel. 1953. Languages in Contact. The Hague: Mouton.

\section{APPENDIX A}

Answer sheet with suggested places of origins of speakers in taped conversation

¿De dónde cree usted que podría ser esta persona?

'Where do you think this person could be from?'

a) de Tamaulipas (northern Mexican state)

b) de Veracruz (Mexican state -and city of the same name- bordering the Gulf of Mexico)

c) de Guerrero (Mexican state bordering the Pacific Ocean)

d) de Jalisco (Mexican state also bordering the Pacific Ocean)

e) de Estados Unidos 'United States' (mexicoamericano 'Mexican American')

f) de un pueblo pequeño en México 'from a small town in Mexico'

g) del campo en México 'from the countryside in Mexico'

h) de otro país 'from another country' (Escriba el nombre 'Write the name') 